\title{
Soil Quality Assessment in Relation to Food Crop Productivity to Support Agribusiness-Based of Dry Land Management by Scoring of Soil Quality
}

\author{
L M Rachman $^{1 *}$ \\ ${ }^{1}$ Department of Soil Science and Land Resource, Faculty of Agriculture, IPB University \\ *Email: latiefra@apps.ipb.ac.id
}

Article Information:
Received:
12 March 2020
Received in revised form:
2 May 2020
Accepted:
5 May 2020
Volume 2 , Issue 1 , June 2020
pp. $16-24$
C Universitas Lampung
http: / dx.doi.org/
$10.23960 /$ jesr.v2i1. 38

\begin{abstract}
To support Indonesian's food self-sufficiency program, more quantitative and accurate data are required on the character of soil data needed, which can be more easily understood, practical and suitable for crop selection as well as for the right fertilizer recommendations to support the agribusiness development, implementation and operation. The purpose of this research is to develop and assess soil quality in relation to the productivity of major food crops by using Soil Quality Score Plus (SQS Plus) to support agribusiness-based management of dry lands. The use of SQS for assessing soil quality in principle determines the weighted average score obtained from the score of each selected key parameter multiplied by its weight. The SQS for the 36 locations observed varies from 2.36 (low) to 4.12 (high). SQS Plus adds letter(s) after a score to indicate the limiting factor(s) of soil ecosystem. The most limiting factor is low carbon organic content (72.2 \% from the 36 locations observed), followed by low $P$ availability (58.3\%), and low total organic N (41.7\%). Data of correlation between SQS and crop productivity is not good as expected. Crop growth and crop production are not only determined by soil quality and its limiting factors.
\end{abstract}

Keywords: Crop productivity, dry land management, soil limiting factors, soil quality assessment, Soil Quality Score

\section{INTRODUCTION}

$\mathrm{T}_{\mathrm{s}}$ support Indonesia's program to achieving food self-supporting and food independence, the country is now accelerating the implementation of Agriculture 3.0 in tandem Agriculture 4.0. Agriculture 3.0 is characterized by precise farming and smart farming, whereas Agriculture 4.0 indicated by digitalization. As a consequence, agribusiness development and operation require more accurate and detailed data on soil resources.

Data on soil quality is needed to fill the void created by the shortage of data and information provided by Soil Map and Land Suitability Map, two maps that are currently for obtaining information on soil and land. More quantitative soil data is required on the character or type of soil data needed which can be easily to understood, practical and suitable for crop selection, agricultural management, as well as the right fertilizer recommendations to support the agribusiness development, implementation and operation.

Soil quality (SQ) is defined as the capacity of a soil to function within ecosystem boundaries to sustain biological productivity, maintain environmental quality and promote the health of plants and animals [1]. Soil physical, chemical and biological properties provide information on various aspects of soil as a system [2]. SQ is a useful concept to assess the sustainability of agricultural activities [3] and shows the capacity of soil to maintain crops and animal productivity, to maintain or improve the quality of water and air, and to protect human health [4]-[5]. SQ relates to proper soil management to ensure soil conservation which is essential for sustaining our lives and the global community [6]. SQ depends on how the soil their function or fulfil the purpose of their use [7]. In the context of agricultural production, high soil quality therefore corresponds to high productivity and long-term system resilience without significant soil or environmental degradation [6]-[8].

The purpose of determining SQ is to support land and soil management practices and the use of land and soil over time to help evaluate whether the agriculture practice sustain or improve SQ [9]. SQ assessment is useful for two purposes: 1) as a management tool for farmers and other land users, and 2) as a sustainability 
measurement. Both are closely related to the responsibility to restore soil quality and vitality in the interests of future generations [1]. SQ and its evaluation can be considered a comprehensive index for assessing sustainable land or soil management particularly as soil is a highly complex medium. The quality of agricultural soil is related to their physical, chemical and biological components [10]-[11]. Soil quality index is needed for identifying to their productionrelated issues, making realistic food production estimates, evaluating agricultural systems and land or soil management to monitor changes in quality and ensuring environmental conservation and sustainability in relating to agricultural management. SQ also can be used for evaluating the benefits of public investment in agricultural policy and programs. SQ is assessed by identifying soil properties as key indicator of soil quality that meet certain criteria. Soil properties should be measurable, accessible, unique yet represent soil conditions; and "fairly sensitive" to changes in soil and environmental management. In relation to the effect of a soil management system in a certain period of time, the assessment at least SQ can be classified as declining, unchanged, or improving. SQ can be assessed in a descriptive and analytical manner. A descriptive assessment is determined by physical appearance, colour, taste, and smell. Meanwhile, an analytical assessment involves the quantitative identification of physical, chemical and biological characteristics [12].

The physical, chemical and biological parameters of soil are often used for evaluating soil or soil management systems for various activities, especially in farming, plantations, and environmental evaluation. The physical properties of soil are the most difficult to improve in the event of damage [13]. Its chemical properties are the fastest to change, either increasing or decreasing. Soil biological properties fall between the two. Even though the content of soil organic matter generally ranges from only $1-6 \%$, in the combined form of non-living organic matter, soil biota and plant roots, it is now time for us to pay more attention to assessing soil biological components that play a significant role as a determining factor in various soil systems processes, and to its physical, chemical, and biological attributes. The presence of organic matter in the soil makes soil a living and active system [14]. In its "living" state, soil can naturally recovery and fertilize [15]. According to [16], SQ assessment is crucial to maintain and boost the productivity of agricultural commodities needed to support food independence. SQ assessment looks at soil status or condition to monitor and evaluate SQ damage or improvement due to soil or land management over a certain period of time. SQ monitoring and evaluation is necessary to review and redesign the soil of land management systems in order to ensure a sustainable soil and land use system.
The purpose of this research is to develop soil assessment system based on soil quality by scoring of soil quality in relation to food crops productivity to support agribusiness-based dry land management.

\section{MATERIALS AND METHODS}

\section{A. Number and Location of Dry Land Soil Sampling in Banten Province}

Research and sampling of soil took place at 36 locations from which 12 locations are corn-growing areas, another 12 soybeans-growing areas, and the remaining 12 locations cultivate groundnuts; all dispersed across Banten Province in the regency of Pandeglang and Serang and the cities of Serang and Cilegon.

\section{B. Soil Quality Assessment Techniques and Stages by obtaining Soil Quality Score (SQS)}

SQ is determined according to information on soil physical, chemical, and biological attributes that are being observed or modeled [17]. The technique is to identify a specific set of soil attributes that can be used as SQ standards indicators that are meaningful and sensitive to management-driven change [6]. SQ assessment that obtaining Soil Quality Score (SQS) essentially determines the weighted average score obtained from the score of each selected key parameter multiplied by its weight.

The first step in obtaining SQS is the selection of a set of minimum data from key parameters to determine the quality of dry land soil (20 parameters) together with the weight coefficient and symbol based on its function (see Table 1).

\section{Obtaining of Soil Quality Score (SQS) Plus and Categorization}

The SQS will be followed by a key parameter symbol that serves as the limiting factor(s) (parameters with a value that equal or is less than $2(\leq 2.00)$ falls under the low category). SQS are divided into 7 categories (see Table 3). 
Table 1. The selected key parameters for scoring of soil quality of dry land soil, together with symbols, and weighted coefficients and methods used.

\begin{tabular}{|c|c|c|c|c|}
\hline No & Symbol & Key Parameter & $\mathrm{WC}^{*}$ & Method \\
\hline \multicolumn{5}{|c|}{ Physical Properties } \\
\hline 1 & $\mathrm{~S}$ & Effective soil depth & 0.07 & Field Observation \\
\hline 2 & $\mathrm{~T}$ & Texture & 0.07 & Pipet \\
\hline 3 & $\mathrm{~B}$ & Bulk density & 0.07 & Core sample, Gravimetric \\
\hline 4 & $\mathrm{D}$ & Drainage & 0.04 & Field Observation \\
\hline 5 & $\mathrm{Pe}$ & Permeability & 0.03 & De Boodt \\
\hline 6 & $\mathrm{Aw}$ & Available water & 0.06 & Plate and Membrane Apparatus-Gravimetric \\
\hline \multicolumn{5}{|c|}{ Chemical Properties } \\
\hline 7 & $\mathrm{pH}$ & $\mathrm{pH}$ & 0.06 & $\mathrm{pH}-\mathrm{H}_{2} \mathrm{O}$ \\
\hline 8 & $\mathrm{C}$ & Cation Exchange Capacity & 0.06 & Extraction of $\mathrm{NH}_{4} \mathrm{OAc} 1 \mathrm{M} \mathrm{pH} 7.0$ \\
\hline 9 & Bs & Base saturation & 0.03 & Extraction of $\mathrm{NH}_{4} \mathrm{OAc} 1 \mathrm{M} \mathrm{pH} 7.0$ \\
\hline 10 & $\mathrm{~N}^{* *}$ & Total organic Nitrogen & 0.07 & Kjehdahl \\
\hline 11 & $\mathrm{P}^{* *}$ & Available Phosphor & 0.06 & Bray I \\
\hline 12 & $\mathrm{Po}^{* *}$ & Exchangeable Potassium & 0.06 & Extraction of $\mathrm{NH}_{4} \mathrm{OAc} 1 \mathrm{M} \mathrm{pH} 7.0$ \\
\hline 13 & $\mathrm{Ca}^{* * *}$ & Exchangeable Calcium & 0.04 & Extraction of $\mathrm{NH}_{4} \mathrm{OAc} 1 \mathrm{M} \mathrm{pH} 7.0$ \\
\hline 14 & $\mathrm{Mg}^{* *}$ & Exchangeable Magnesium & 0.04 & Extraction of $\mathrm{NH}_{4} \mathrm{OAc} 1 \mathrm{M} \mathrm{pH} 7.0$ \\
\hline 15 & $\mathrm{Al}^{* * * *}$ & Aluminum Saturation & 0.04 & Extraction of $\mathrm{KCl}$, filtering, and titration \\
\hline 16 & $\mathrm{Fe}^{* * * *}$ & Fe (Ferri) & 0.02 & Dry ashing with extracting a mixture of $\mathrm{HNO}_{3}$ and $\mathrm{HClO}_{4}$ \\
\hline 17 & $\mathrm{Cu}^{* * * *}$ & $\mathrm{Cu}$ (Cuprum) & 0.02 & Dry ashing with extracting a mixture of $\mathrm{HNO}_{3}$ and $\mathrm{HClO}_{4}$ \\
\hline 18 & $\mathrm{Zn}^{* * * *}$ & Zn (Zink) & 0.02 & Dry ashing with extracting a mixture of $\mathrm{HNO}_{3}$ and $\mathrm{HClO}_{4}$ \\
\hline & $\mathrm{Mn}^{* * * *}$ & Mn (Mangan) & 0.02 & Dry ashing with extracting a mixture of $\mathrm{HNO}_{3}$ and $\mathrm{HClO}_{4}$ \\
\hline \multicolumn{5}{|c|}{ Biological Property } \\
\hline 20 & $\mathrm{Oc}^{* *}$ & Organic Carbon & 0.12 & Walkey and Black \\
\hline & & Total & 1.00 & \\
\hline
\end{tabular}

Remarks: ${ }^{*} \mathrm{WC}=$ weighting coefficient ${ }^{* *}$ Macro elements; ${ }^{* * *}$ Micro elements

The next step is to determine the score each parameter, score 0 (worst) to 5 (best) for each parameter, according to the conditions and performance as provided in Table 2 .

Table 2. Criteria for scoring of each parameter

\begin{tabular}{|c|c|c|c|c|c|c|c|}
\hline \multirow{2}{*}{ Key parameters } & \multirow{2}{*}{ Unit } & \multicolumn{6}{|c|}{ Score of each parameter } \\
\hline & & $\mathbf{0}$ & 1 & 2 & 3 & 4 & 5 \\
\hline \multicolumn{8}{|l|}{ Physical Properties } \\
\hline Effective depth & $\mathrm{cm}$ & $<10$ & $10-20$ & $20-40$ & $40-60$ & $60-80$ & $>80$ \\
\hline Texture & & $\mathrm{S}$ & $\mathrm{LS}$ & $\mathrm{HC}^{*}$ & $\mathrm{C}, \mathrm{SL}$ & $\begin{array}{c}\text { SC, SiL, Si } \\
\text { SiC }\end{array}$ & $\begin{array}{l}\text { L, SiCL, } \\
\text { CL, SCL }\end{array}$ \\
\hline Bulk density & $\mathrm{g} / \mathrm{cm}^{3}$ & $>1.6$ & $1.4-16$ & $1.2-1.4$ & $1.0-1.2$ & $0.8-1.0$ & $<0.8$ \\
\hline Drainage & & Very bad & Bad & $\begin{array}{l}\text { Slightly } \\
\text { Bad }\end{array}$ & Fair & $\begin{array}{l}\text { Slightly } \\
\text { Good }\end{array}$ & Good \\
\hline Permeability & $\mathrm{cm} / \mathrm{jam}$ & $<0.025$ & $0.025-0.125$ & $0.125-0.50$ & $\begin{array}{c}0.5-2.0 \text { and } \\
>25.0\end{array}$ & $\begin{array}{c}2.00-6.25 \text { and } \\
12.5-25.0\end{array}$ & $6.25-12.50$ \\
\hline Available water & $\%$ & $<2$ & $2-4$ & $4-8$ & $8-12$ & $12-16$ & $>16$ \\
\hline \multicolumn{8}{|l|}{ Chemical Properties } \\
\hline $\mathrm{pH}$ & & $\begin{array}{l}<4.0 \text { and } \\
>9.5\end{array}$ & $\begin{array}{c}4.0-4.5 \text { and } \\
9.0-9.5\end{array}$ & $\begin{array}{c}\text { 4.5-5.1 and } \\
8.5-9.0\end{array}$ & $\begin{array}{l}\text { 5.1-5.8 and } \\
8.0-8.5\end{array}$ & $\begin{array}{l}\text { 5.8-6.6 and } \\
7.5-8.0\end{array}$ & $6.6-7.5$ \\
\hline Cation Exchange Capacity & $\mathrm{me} / 100 \mathrm{~g}$ & $<2$ & $2-5$ & $5-16$ & $17-24$ & $25-40$ & $>40$ \\
\hline Base saturation & $\%$ & $<10$ & $10-20$ & $20-40$ & $40-60$ & $60-80$ & $>80$ \\
\hline Total organic Nitrogen & $\%$ & $<0.05$ & $0.05-0.1$ & $0.11-0.2$ & $0.21-0.5$ & $0.51-0.75$ & $>0.75$ \\
\hline Available Phosphor & ppm & $<2$ & $2-4$ & $5-7$ & $8-10$ & $11-15$ & $>15$ \\
\hline Exchangeable Potassium & $\mathrm{me} / 100 \mathrm{~g}$ & $<0.05$ & $0.05-0.1$ & $0.1-0.3$ & $0.4-0.5$ & $0.6-1$ & $>1$ \\
\hline Exchangeable Calcium & $\mathrm{me} / 100 \mathrm{~g}$ & $<1$ & $1-2$ & $2-5$ & $6-10$ & $11-20$ & $>20$ \\
\hline Exchangeable Magnesium & $\mathrm{me} / 100 \mathrm{~g}$ & $<0.1$ & $0.1-0.3$ & $0.4-1$ & $1.1-2$ & $2.1-8$ & $>8$ \\
\hline Aluminum Saturation & $\%$ & & $>40$ & $20-40$ & $10-20$ & $5-10$ & $0-5$ \\
\hline Ferri (Fe) & ppm & $\begin{array}{l}<1.0 \text { and } \\
>1500\end{array}$ & $\begin{array}{c}1.0-2.5 \text { and } \\
900-1500\end{array}$ & $\begin{array}{c}2.5-4.0 \text { and } \\
600-900\end{array}$ & $\begin{array}{c}4.0-6.0 \text { and } \\
300-600\end{array}$ & $\begin{array}{c}6.0-20.0 \text { and } \\
53-300\end{array}$ & $20.0-53.0$ \\
\hline Cuprum $(\mathrm{Cu})$ & ppm & $\begin{array}{c}<0.10 \text { and } \\
>30\end{array}$ & $\begin{array}{c}0.1-0.2 \text { and } \\
18.0-30.0\end{array}$ & $\begin{array}{c}0.2-0.5 \text { and } \\
10.0-18.0\end{array}$ & $\begin{array}{c}0.4-0.6 \text { and } \\
5.0-10.0\end{array}$ & $\begin{array}{c}0.6-1.0 \text { and } \\
1.50-5.0\end{array}$ & $1.0-1.5$ \\
\hline
\end{tabular}




\begin{tabular}{|c|c|c|c|c|c|c|c|}
\hline \multirow{2}{*}{ Key parameters } & \multirow{2}{*}{ Unit } & \multicolumn{6}{|c|}{ Score of each parameter } \\
\hline & & $\mathbf{0}$ & 1 & 2 & 3 & 4 & 5 \\
\hline Zink (Zn) & ppm & $\begin{array}{c}<0.10 \text { and } \\
>50\end{array}$ & $\begin{array}{c}0.1-0.3 \text { and } \\
30-50\end{array}$ & $\begin{array}{c}0.3-0.6 \text { and } \\
15-30\end{array}$ & $\begin{array}{c}0.7-1.0 \text { and } \\
5-15\end{array}$ & $\begin{array}{c}1.0-1.4 \text { and } \\
2-5\end{array}$ & $1.4-2.0$ \\
\hline Mangan (Mn) & ppm & $\begin{array}{c}<0.5 \text { and } \\
>1500\end{array}$ & $\begin{array}{c}0.5-1.0 \text { and } \\
900-1500\end{array}$ & $\begin{array}{c}1.0-1.5 \text { and } \\
300-900\end{array}$ & $\begin{array}{c}1.5-3.0 \text { and } \\
100-300\end{array}$ & $\begin{array}{c}3.0-9.0 \text { and } \\
23-100\end{array}$ & $9.0-23.0$ \\
\hline \multicolumn{8}{|l|}{ Biological Properties } \\
\hline Organic Carbon & $\%$ & $<0.5$ & $0.5-1$ & $1-2$ & $2-3$ & $3-5$ & $>5$ \\
\hline
\end{tabular}

Remark: $\mathrm{C}=$ clay, $\mathrm{HC}=$ heavy clay (clay content $>80 \%$ ), $\mathrm{Si}=$ silt, $\mathrm{S}=$ sand, $\mathrm{L}=$ loam, $\mathrm{SiC}=$ silty clay, $\mathrm{SC}=$ sandy clay, $\mathrm{CL}=$ clay loam, $\mathrm{SiL}=$ silty loam, $\mathrm{SL}=$ sandy loam, $\mathrm{SiCL}=$ silty clay loam, $\mathrm{SCL}=$ sandy clay loam, $\mathrm{LS}=$ loamy sand

Table 3. Categorization of Soil Quality Score (SQS)

\begin{tabular}{cccccccc}
\hline \hline SQ Score & $\mathrm{x} \leq 2.0$ & $2.0<\mathrm{x} \leq 2.5$ & $2.5<\mathrm{x} \leq 3.0$ & $3.0<\mathrm{x} \leq 3.5$ & $3.5<\mathrm{x} \leq 4.0$ & $4.0<\mathrm{x} \leq 4.5$ & $\mathrm{x} \geq 4.5$ \\
\hline Category & Very low & Low & Slightly low & Medium & Slightly High & High & Very High \\
\hline \hline
\end{tabular}

\section{RESULTS AND DISCUSSIONS}

\section{A. Soil Quality Score Plus (SQS Plus)}

The SQ of 36 observed locations varies, as shown by SQS Plus. The higher the SQS, the better is the quality of soil. The highest SQS (4.11) is found in location 12 under the high category, whereas the lowest SQS (2.34) is observed in location 30 under the slightly low category (see Table 4).

Out of the 36 observed locations, only one location (2.8\%) has high-quality soil, 9 locations $(25.0 \%)$ with slightly high quality, 15 locations $(41.7 \%)$ mediumquality soil, 10 locations (27.8\%) slightly low quality and 1 location (2.8\%) with low-quality soil.

Apart from SQS, another aspect where attention should be given is the letters that after the SQS, which show the limiting factors for plant growth and crop production. More letters after the SQS means that there are more limiting factors to support crop growth and production. There lower SQS, the greater the likelihood of having more letters after the numbers. The most limiting factor is low organic carbon content which occurs in $72.2 \%$ of the 36 locations observed. This is followed by low available $\mathrm{P}(58.3 \%)$, low total organic $\mathrm{N}(41.7 \%)$, low soil $\mathrm{pH}$ or acidic soil (38.8\%), low-level of exchangeable $\mathrm{Ca}(38.8 \%)$, low-level of exchangeable K (36.1\%), low-level Cation Exchange Capacity (30.6\%) and low level of exchangeable $\mathrm{Mg}$ (25.0\%). Meanwhile, for minor elements, 4 locations (11.1\%) have high Mn content.

In terms of soil physical properties, 8 locations (22.2\%) have fairly high compaction or soil bulk density and 6 locations (16.7\%) have low water availability.

\section{B. The Role of SQS Plus for Agribusiness Based Dry Land management}

Unlike traditional agriculture land management, the agribusiness-based management of dry lands soils require more accurate and precise data and information on limiting soil factors to meet all conditions and support all aspect needed for plant to grow well, and ultimately achieve optimal production. SQS Plus that is supported by limiting soil factor(s) will help land management systems better anticipate and be well-prepared on what is needed for achieving optimal crop production.

\section{Relationship between Soil Quality Score (SQS) and Crop Production}

Data of relationship between SQS and crop production of different commodities together with their limiting factors at different locations is presented in Table 5 .

In conceptual, an increase in SQS will be followed by an increase in plant production. However, data obtained from this research are not as good as expected. Plant growth and crop production are not only determined by soil quality and its limiting factors. There are other external factors or other elements that control plant growth and production, especially the fertilizing system, drought, flooding, and pest and plant disease. From the three commodities, the best correlation is observed between SQS and soybean production (see Fig. 1). 
Table 4. Physical, chemical, and biological properties of soil and SQS plus of researched soils.

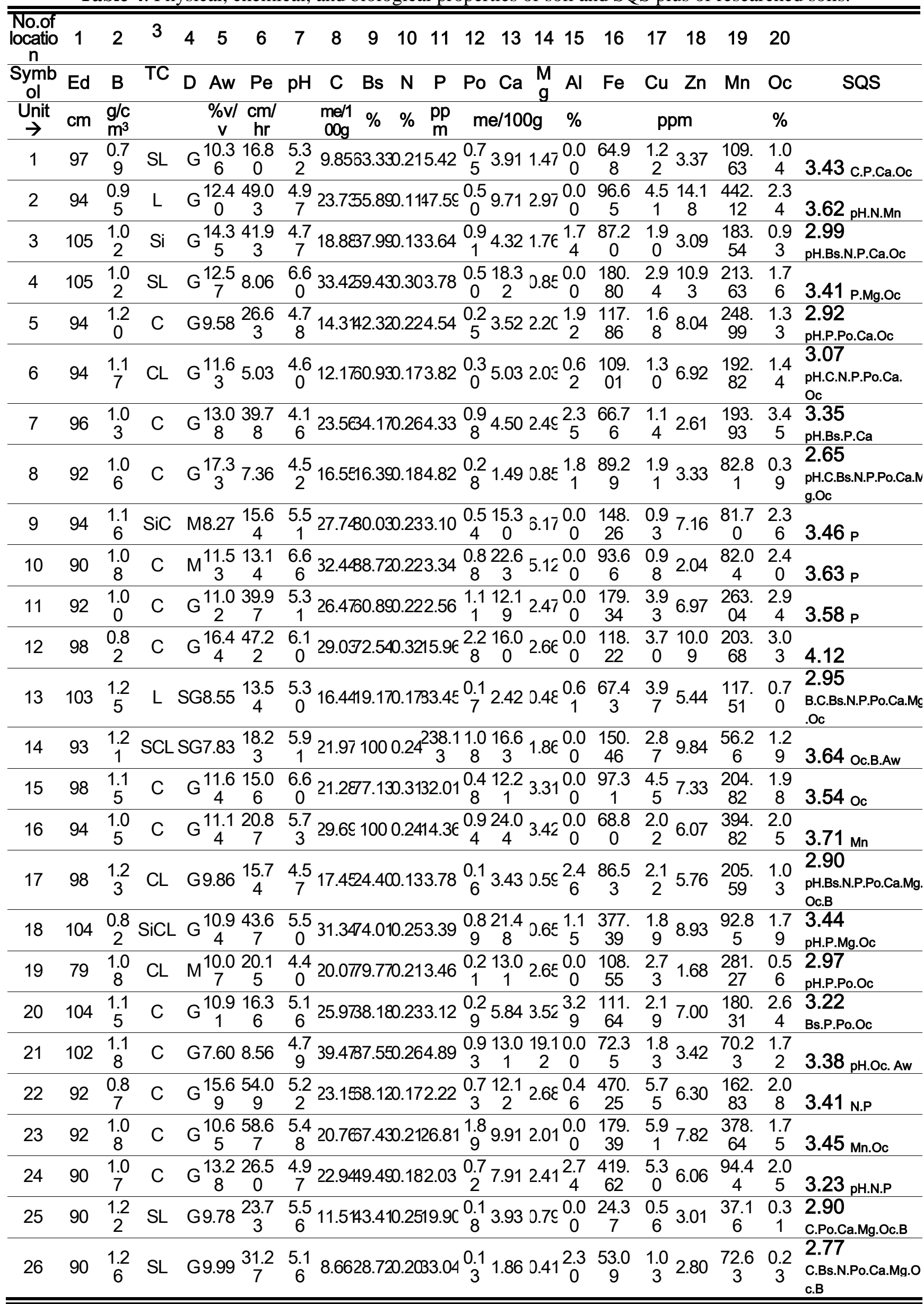




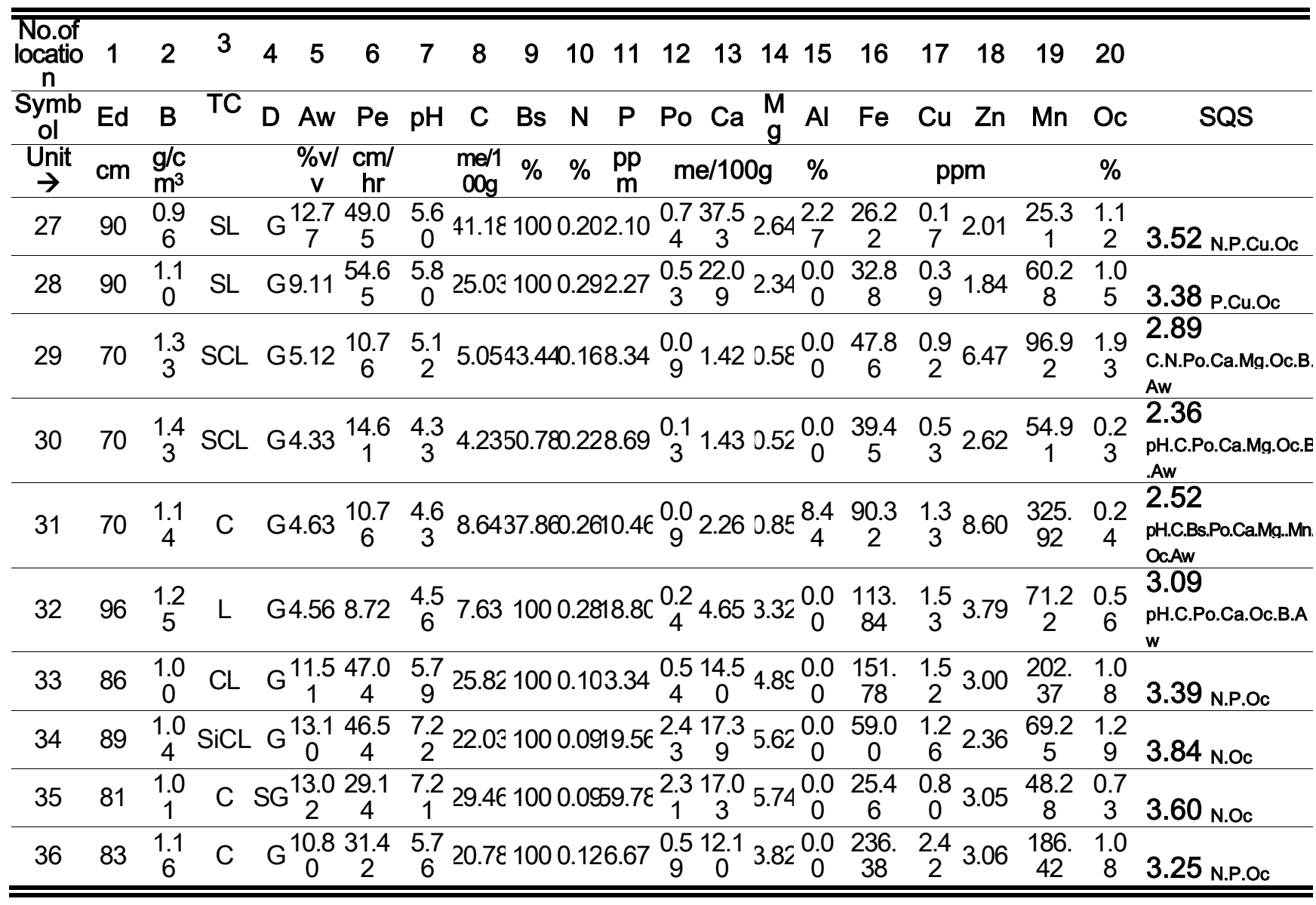

Remark: $\mathrm{TC}=$ texture class $; \mathrm{C}=$ clay $: \mathrm{HC}=$ heavy clay $: \mathrm{L}=$ loam $: \mathrm{CL}=$ clay loam $; \mathrm{SL}=$ sandy loam $: \mathrm{SiL}=$ silty loam; $\mathrm{SCL}=$ sandy clay loam $; \mathrm{SiC}=$ silty clay; $\mathrm{SiCL}=$ silty clay loam $; \mathrm{G}=\operatorname{good} ; \mathrm{SG}=$ slightly good $; \mathrm{M}=$ medium $; \mathrm{Ed}=$ effective depth : $\mathrm{B}=$ bulk density $; \mathrm{T}=$ texture, $\mathrm{D}=$ drainage $; \mathrm{Pe}=$ permeability $; \mathrm{Aw}=$ available water $; \mathrm{pH}=$ soil $\mathrm{pH} ; \mathrm{C}=$ cation exchange capacity $; \mathrm{Bs}=$ base saturation $; \mathrm{N}=$ total organic nitrogen $; \mathrm{P}=$ available phosphor $; \mathrm{Po}=$ exchangeable potassium $; \mathrm{Ca}=$ exchangeable calcium $; \mathrm{Mg}=$ exchangeable magnesium $; \mathrm{Al}=$ Aluminium saturation; $\mathrm{Oc}=$ organic carbon $;$ Minor elements $(\mathrm{Fe}=$ ferri $; \mathrm{Cu}=$ cuprum $; \mathrm{Zn}=\mathrm{zink} ; \mathrm{Mn}=$ mangan $)$

Table 5. Relationship between SQS and crop production of different commodities together with their limiting factors at different locations

\begin{tabular}{|c|c|c|c|c|c|}
\hline No & Location (Village/District) & Comodity & $\begin{array}{c}\text { Production* } \\
\text { (ton/ha) }\end{array}$ & SQS & Limiting factor(s) \\
\hline \multicolumn{6}{|c|}{ Serang Regency } \\
\hline 1 & Cikoneng/Anyer & Corn & 5.24 & 3.43 & C.P.Ca.Oc \\
\hline 2 & Gunungsari/Gunungsari & Corn & 3.85 & 3.62 & pH.N.Mn \\
\hline 3 & Taman Sari/Baros & Corn & 2.83 & 2.99 & pH.Bs.N.P.Ca.Oc \\
\hline 4 & Pasir Kembang/Pamarayan & Corn & 3.96 & 3.41 & P.Mg.Oc \\
\hline \multicolumn{6}{|c|}{ Lebak Regency } \\
\hline 5 & Narimbang Mulya/Rangkasbitung & Corn & 3.45 & 2.92 & pH.P.Po.Ca.Oc \\
\hline 6 & Citeras/Rangkasbitung & Corn & 3.08 & 3.07 & pH.C.N.P.Po.Ca.Oc \\
\hline & Gunung Kandang/Gunung Kencana & Corn & 3.67 & 3.35 & pH.Bs.P.Ca \\
\hline
\end{tabular}




\begin{tabular}{|c|c|c|c|c|c|}
\hline No & Location (Village/District) & Comodity & $\begin{array}{c}\text { Production* } \\
\text { (ton/ha) }\end{array}$ & SQS & Limiting factor(s) \\
\hline 8 & Gunung Kandang/Gunung Kencana & Corn & 2.93 & 2.65 & pH.C.Bs.N.P.Po.Ca.Mg.Oc \\
\hline \multicolumn{6}{|c|}{ Pandeglang Regency } \\
\hline 9 & Tanjung Jaya/Panimbang & Corn & 4.58 & 3.46 & $\mathrm{P}$ \\
\hline & Curung Ciung/Cikeusik & Corn & 4.31 & 3.63 & $\mathrm{P}$ \\
\hline & Kadumadang/Kadumadang & Corn & 4.98 & 3.58 & $\mathrm{P}$ \\
\hline & Pasir Kembang/Mandalawangi & Corn & 3.76 & 4.12 & - \\
\hline \multicolumn{6}{|c|}{ Serang Regency } \\
\hline & Wanakerta/Bojonegara & Soybean & 0.94 & 2.95 & B.C.Bs.N.Po.Ca.Mg.Oc \\
\hline & Wanakerta/Bojonegara & Soybean & 1.23 & 3.64 & B.A.Oc \\
\hline & Mancak/Mancak & Soybean & 1.17 & 3.54 & Oc \\
\hline & Winong/Mancak & Soybean & 1.36 & 3.71 & $\mathrm{Mn}$ \\
\hline \multicolumn{6}{|c|}{ Lebak Regency } \\
\hline & Citeras/Rangkasbitung & Soybean & 0.79 & 2.90 & B.pH.Bs.N.P.Po.Ca.Mg.Oc \\
\hline & Cilangkap/Kalanganyar & Soybean & 1.15 & 3.44 & Ph.P.Mg.Oc \\
\hline & Selaraja/ Warung Gunung & Soybean & 0.83 & 2.97 & pH.P.Po.Oc \\
\hline & Taman Jaya/Cikulur & Soybean & 1.28 & 3.22 & Bs.P.Po.Ca \\
\hline \multicolumn{6}{|c|}{ Pandeglang Regency } \\
\hline & Tanjung Jaya/Panimbang & Soybean & 1.22 & 3.38 & Aw.pH.P.Oc \\
\hline & Cipeucang/Cipeucang & Soybean & 1.36 & 3.41 & N.P \\
\hline & Kadumadang/Kadumadang & Soybean & 1.43 & 3.45 & Mn.Oc \\
\hline & Pasir Kembang/Mandalawangi & Soybean & 0.86 & 3.23 & pH.N.P \\
\hline \multicolumn{6}{|c|}{ Serang Regency } \\
\hline & Sukarame/Cikeusal & Peanut & 1.03 & 2.90 & B.C.Po.Ca.Mg.Oc \\
\hline & Sidamukti/Baros & Peanut & 0.94 & 2.77 & B.C.Bs.N.Po.Ca.Mg.Oc \\
\hline & Pudar/Pamarayan & Peanut & 1.26 & 3.52 & N.P.Cu.Oc \\
\hline & Bojongnangka/Petir & Peanut & 1.34 & 3.38 & P.Cu.Oc \\
\hline \multicolumn{6}{|c|}{ Serang City } \\
\hline & Umbul Tengah/Taktakan & Peanut & 0.79 & 2.89 & B.Aw.C.N.Po.Ca.Mg.Oc \\
\hline & Egalsari/Telaga Sari & Peanut & 0.82 & 2.36 & B.Aw.pH.C.Po.Ca.Mg.Oc \\
\hline & Pasuruan /Walantaka & Peanut & 0.94 & 2.52 & Aw.pH.C.Bs.Po.Ca.Mg.Oc \\
\hline & Walantaka/Walantaka & Peanut & 1.13 & 3.09 & B.Aw.pH.C.Po.Ca.Oc \\
\hline \multicolumn{6}{|c|}{ Cilegon City } \\
\hline & Tegal Bunder/Purwakarta & Peanut & 1.04 & 3.39 & N.P.Oc \\
\hline & Pabean Village/Purwakarta & Peanut & 1.28 & 3.84 & N.Oc \\
\hline & Tegal Bunder/Purwakarta & Peanut & 1.15 & 3.60 & N.Oc \\
\hline & Tegal Bunder/Purwakarta & Peanut & 0.98 & 3.25 & N.P.Oc \\
\hline
\end{tabular}

Remarks: * dry grain ; $\mathrm{T}=$ soil texture $; \mathrm{B}=$ bulk density ; $\mathrm{A}=$ available water $; \mathrm{C}=$ cation exchange capacity $; \mathrm{Bs}=$ base saturation $; \mathrm{pH}=$ soil $\mathrm{pH} ; \mathrm{N}=$ total organic nitrogen $; \mathrm{P}=$ available phosphor $; \mathrm{Po}=$ exchangeable potassium $; \mathrm{Ca}=$ exchangeable calcium ; $\mathrm{Mg}=$ exchangeable magnesium ; Oc $=$ organic carbon ; Minor elements $(\mathrm{Fe}=$ ferry $; \mathrm{Cu}=\mathrm{cuprum} ; \mathrm{Zn}$ $=$ zink $;$ Mn = mangan)

\section{Correlation between SQS and Soybean Production}

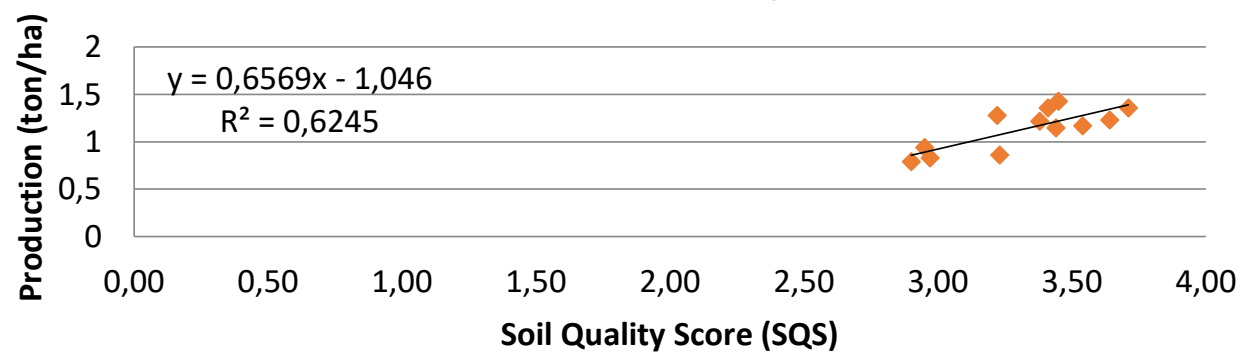




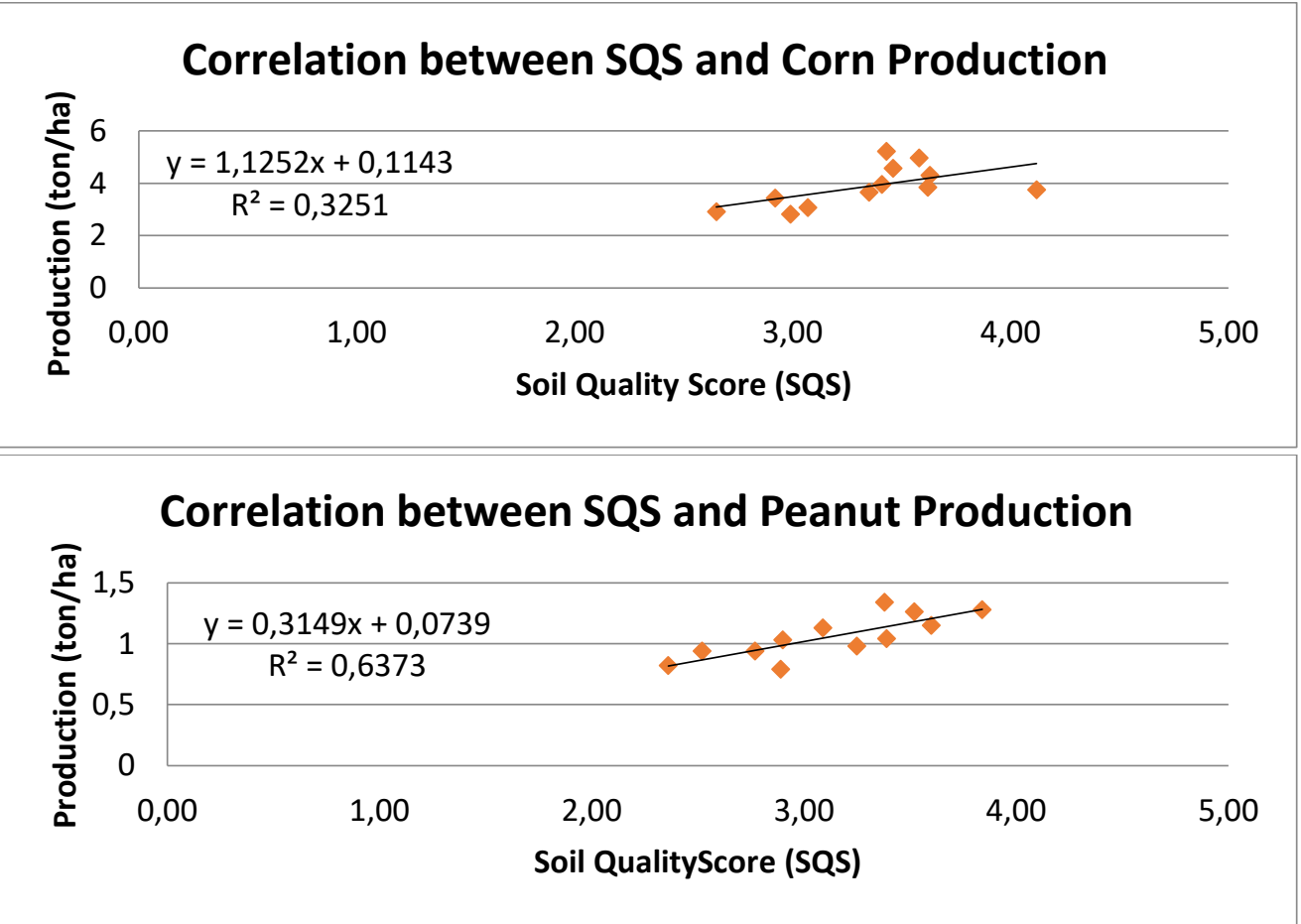

Figure 1. Correlation between SQS and Soybean Production (above), Corn Production (middle), and Peanut Production (below).

\section{Conclusions}

The SQS system was successfully developed to assess soil quality based on the scoring of some soil properties with considering their weighting coefficient in relation to food crops productivity to support agribusiness-based dry land management.

Out of the 36 observed locations, only one location classified as high-quality soil, 9 locations with slightly high quality, 15 locations are medium-quality soil, 10 locations are slightly low quality and 1 location is lowquality soil. Many soil chemical properties were found as limiting factors for crop growth and production, i.e. organic Carbon, available Phosphor, total organic Nitrogen, exchangeable Calcium, Potassium and Magnesium, low soil $\mathrm{pH}$ and Cation Exchange Capacity.

The SQS system offers advantage for agribusiness based dry land management since it provides limiting factor(s) for crop growth and production.

\section{ACKNOWLEDGMENT}

The author wishes to extend the utmost gratitude to the Ministry of Research Technology, Research and Higher Education of the Republic of Indonesia for the financial support provided in the form of a research grant of the Higher Education Advanced Applied Research Scheme.

\section{REFERENCES}

[1] J. W. Doran and T. B. Parkin, "Defining and assessing soil quality," in Defining Soil Quality for A Sustainable Environment, J. W. Doran, D. C. Coleman, D.F. Bezdicek, and B. A. Stewart, Ed. USA: Soil Science Society of America and American Society of Agronomy, 1994, pp. $1-21$.

[2] S. M. Zuber, G. D. Behnke, E. D. Nafziger, and M. B. Villamil. (2017). Multivariate assessment of soil quality indicators for crop rotation and tillage in Illinois. Soil and Tillage Research. 174, pp. $147-155$.

[3] J. W. Doran, M. Sarrantonio, and M. Liebig, "Soil health and sustainability," in Advanced in Agronomy, $56^{\text {th }}$ ed. D. L. Sparks, Ed. San Diego: Academic Press, 1996, pp. $1-54$.

[4] J. L. Karlen, J. C. Gardner, and M. J. Rosek. (1998). A soil quality framework for evaluating the impact of CRP. Journal of Production Agriculture. 11(1), pp. 56 -60 .

[5] S. M. J. Sione, M. G. Wilson, M. Lado, and A. Paz Gonzalez. (2017). Evaluation of soil degradation produced by rice crop system in vertisol using a soil quality index. Catena. 150, pp. $79-86$.

[6] M. Kiani, G. H. Ramire, S. Quideau, E. Smith, and H. Janzen. (2917). Quantifying sensitive soil quality indicators across contrasing long - term management system : crop rotations and nutrient regime. Agriculture, Ecosystem, and Environment. 248, pp. 123 - 135.

[7] D. L. Karlen, S. S. Andrews, B. J. Weinhold, and J. W. Doran. (2003). Soil quality: humankind's foundation for survival a research editorial by conservation proffesionals. Journal of Soil and Water Conservation. 58, pp. $171-179$.

[8] D. L. Karlen, E. G. Hurley, S. S. Andrews, C. A. Cambardella, D. W. Meek, M. D. Duffy, and A. P. Mallarino. (2006). Crop rotation effects on soil quality 
at three northern corn/soybean belt location. Agronomy Journal. 98, pp. $484-495$.

[9] M. P. Jimenez, A. M. de la Horra, L. Pruzzon, and R. M. Palma. (2002). Soil quality: a new index based on microbiological and biochemical parameters. Biology and Fertility of Soil. 35, pp. $302-306$.

[10] M. J. Imaz, I. Virto, P. Bescansca, A. Enrique, O. Fernandex - Ugalde, and D. L. Karlen. (2010). Soil quality indicator response to tillage and residue management on semi - arid Mediterranean cropland. Journal Soil and Tillage Research. 107, pp. $17-25$.

[11] F. Ashwooda, K. R. Butt, K. J. Dooick, and E. I. Vangeuelova. (2017). Interactive effects of composted green wate and earthworm activity on tree growth and reclaimed soil quality: a mesocosm experiment. Applied Soil Ecology. 119, pp. 226 - 233.

[12] R. F. Harris and D. F. Bezdicek, "Descriptive aspects of soil quality health," in Defining Soil Quality for A Sustainable Environment, J. W. Doran, D. C. Coleman, D.F. Bezdicek, and B. A. Stewart, Ed. USA: Soil Science Society of America and American Society of Agronomy, 1994, pp. 23 - 36.
[13] L. M. Rachman, E. D. Wahjunie, K. R. Brata, W. Purwakusuma, and K. Murtilaksono, Fisika Tanah. Bogor: IPB Press.

[14] N. Uphoff, A. Ball, E. Fernandes, H. Herren, O. Husson, M. Laing, C. A. Palm, J. N. Pretty, P. A. Sanchez, N. Sanginga. And J. Theis, Biological Approches to Sustainable Soil System. Boca raton : CRC Press.

[15] L. M. Rachman, "Long Term Effect of Alley Cropping System on Soil Productivity and Soil Quality: Evaluation of Its Sustainability on Soil Resource," Ph.D. dissertation, Dept., Soil. Sci., Los Banos Univ., Philippine. 1997.

[16] L. M. Rachman, "Esensi dan Kebutuhan terhadap Penetapan Kualitas Tanah," in Proc. Lokakarya Nasional dan Seminar Forum Komunikasi Perguruan Tinggi Pertanian Indonesia (FKTPI), 2013, pp. 749 763.

[17] R. Lal. (2001). Mananging world soils for food security and environmental quality. Advanced Agronomy. 74, pp. 155 - 192. 